THE HIDDEN CURRICULUM 



\title{
The Hidden Curriculum
}

FIRST GENERATION STUDENTS

AT LEGACY UNIVERSITIES

\author{
RACHEL GABLE
}

PRINCETON UNIVERSITY PRESS

PRINCETON \& OXFORD 
(C) 2021 by Princeton University Press

Princeton University Press is committed to the protection of copyright and the intellectual property our authors entrust to us. Copyright promotes the progress and integrity of knowledge. Thank you for supporting free speech and the global exchange of ideas by purchasing an authorized edition of this book. If you wish to reproduce or distribute any part of it in any form, please obtain permission.

Requests for permission to reproduce material from this work should be sent to permissions@press.princeton.edu

Published by Princeton University Press

41 William Street, Princeton, New Jersey 08540

6 Oxford Street, Woodstock, Oxfordshire OX20 1TR

press.princeton.edu

All Rights Reserved

ISBN 978-0-691-19076-1

ISBN (e-book) 978-0-691-20108-5

British Library Cataloging-in-Publication Data is available

Editorial: Peter Dougherty and Alena Chekanov

Production Editorial: Jenny Wolkowicki

Jacket design: Layla Mac Rory

Production: Erin Suydam

Publicity: Alyssa Sanford and Kathryn Stevens

Copyeditor: Kelly Clody

This book has been composed in Arno

Printed on acid-free paper. $\infty$

Printed in the United States of America

$\begin{array}{llllllllll}10 & 9 & 8 & 7 & 6 & 5 & 4 & 3 & 2 & 1\end{array}$ 